\begin{tabular}{|c|c|c|c|}
\hline Article Info & RESEARCH ARTICLE & ARAŞTIRMA MAKALESİ & \\
\hline Title of Article & \multicolumn{2}{|c|}{$\begin{array}{c}\text { Evaluation of Botanical Gardens toward to } \\
\text { the Biophilic Design Criteria: Case of } \\
\text { Nezahat Gökyiğit Botanic Garden }\end{array}$} & \\
\hline $\begin{array}{l}\text { Corresponding } \\
\text { Author }\end{array}$ & \multicolumn{2}{|c|}{$\begin{array}{l}\text { Banu KARAŞAH } \\
\text { Artvin Çoruh Üniversitesi, Sanat ve Tasarım Fakültesi, Peyzaj Mimarlığı Bölümü, } \\
\text { banukarasah@artvin.edu.tr }\end{array}$} & \\
\hline $\begin{array}{l}\text { Received Date } \\
\text { Accepted Date }\end{array}$ & \multicolumn{2}{|c|}{$\begin{array}{ll}12.08 .2021 \\
14.09 .2021\end{array}$} & \multirow{4}{*}{ Kent Akademisi } \\
\hline DOI Number & \multicolumn{2}{|l|}{ https://doi.org/10.35674/kent.981889 } & \\
\hline Author / Authors & Banu KARAŞAH & ORCID: 0000-0001-5079-5313 & \\
\hline How to Cite & \multicolumn{2}{|c|}{ 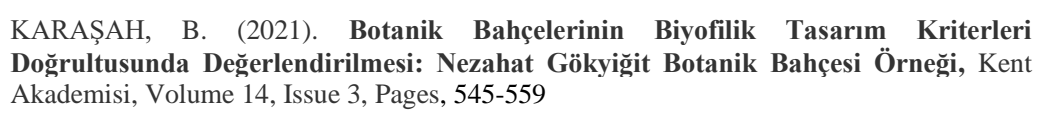 } & \\
\hline
\end{tabular}

\title{
Botanik Bahçelerinin Biyofilik Tasarım Kriterleri Doğrultusunda Değerlendirilmesi: Nezahat Gökyiğit Botanik Bahçesi Örneği
}

\begin{abstract}
:
Biophilic designs are one of the effective design approaches to sustain the human-nature relationship. Interaction with nature has a significant impact on the physical and mental health of individuals. Botanical gardens are also special gardens that help individuals to have a positive attitude towards nature by presenting the beauties of nature to their users, make them feel a part of nature, and especially allow children to satisfy their curiosity towards nature. In this study, it is aimed to scrutinize the biophilic design criteria in the case of Nezahat Gökyiğit Botanic Garden. For this purpose, the 14 criteria of biophilic design (visual connection with nature, non-visual connection with nature, nonrhythmic sensory stimuli, thermal and airflow variability, presence of water, dynamic and diffuse light, connection with natural systems, biomorphic forms and patterns, material connection with nature, complexity and order, prospect, refuge, mystery, and risk/peril) were evaluated using on-site observations and photographic techniques. It has been determined that the botanical garden has only deficiency in terms of material connection with nature among these criteria, and suggestions have been made at this point. Based on the idea that people will be happier and healthier through biophilic designs, suggestions were proposed that biophilic design criteria should be generalized.
\end{abstract}

KEYWORDS: Biophilic design, Botanic gardens, Nezahat Gökyiğit Botanic Garden, İstanbul.

\footnotetext{
${ }^{1}$ Artvin Çoruh University, Faculty of Art and Design, Department of Landscape Architecture, banukarasah@artvin.edu.tr
} 


\section{ÖZ:}

Biyofilik tasarımlar insan-doğa ilişkisinin sürdürülebilmesi için etkili tasarım yaklaşımlarından biridir. Doğayla etkileşimin bireylerin fiziksel ve ruhsal sağlığı üzerinde önemli etkisi vardır. Botanik bahçeleri de kullanıcılarına doğanın güzelliklerini sunarak bireylerin doğaya karşı pozitif tutum sergilemesine yardımcı olan, kendilerini doğanın bir parçası hissetmelerini sağlayan, özellikle çocukların doğaya karşı meraklarını gidermeye imkan tanıyan özel bahçelerdir. Bu çalışmada Nezahat Gökyiğit Botanik Bahçesi örneğinde biyofilik tasarım kriterlerinin irdelenmesi amaçlanmıştır. $\mathrm{Bu}$ amaç doğrultusunda biyofilik tasarımın 14 kriterinin (doğayla görsel bağlantı, doğayla görsel olmayan bağlantı, ritmik olmayan görsel uyarı, termal ve hava akışı değişkenliği, suyun varlığı, dinamik ve dağınık 1şık, doğal sistemlerle bağlantı, biyomorfik biçimler ve dokular, doğayla malzeme bağlantısı ve karmaşa ve düzen, olasılık/manzara, sığınak, gizem ve risk/tehlike) yerinde gözlemler ve fotoğraflama tekniği kullanılarak değerlendirilmesi yapılmıştır. Botanik bahçesinin bu kriterlerden sadece doğayla malzeme bağlantısı noktasında eksilikleri olduğu belirlenmiş ve bu noktada önerilerde bulunulmuştur. Biyofilik tasarımlar sayesinde insanların daha mutlu ve sağlıklı olacağı düşüncesinden hareketle biyofilik tasarım kriterlerinin yaygınlaştırılması gerektiği yönünde önerilerde de bulunulmuştur.

ANAHTAR KELIMELER: Biyofilik tasarım, Botanik bahçeleri, Nezahat Gökyiğit Botanik Bahçesi, İstanbul.

\section{GíRIŞ:}

İnsanoğlu doğduğu ilk günden itibaren doğayla etkileşim halindedir. Doğru planlanan kentleşmenin ve teknolojik gelişmelerin getirileri olduğu kadar maalesef yanlış kentleşme oranı arttıkça doğadan kopma söz konusu olmaktadır. Bu kopma, özellikle kentlerde yaşayan bireyler üzerinde fiziksel ve mental sorunların ortaya çıkmasına neden olmaktadır. Çalışkan ve Çelik Çanga (2018) doğaya erişimin stres, depresyon, ağrı, yorgunluk, saldırganlık, dürtüsellik ve dikkat eksikliği, hiperaktivite bozukluğu gibi sağlık sorunlarının tedavisine katkı sağlamasının yanı sıra bağışıklık sisteminde iyileşme, kemik gücü, yara iyileşmesi, bilinç kazanma, konsantrasyon sağlama, duygusal esneklik kazanma, empati kurma, canlılık kazanma ve rahatlama gibi birçok faydası olduğunu ifade etmişlerdir.

Biyofilik tasarımda bu bağı tekrar kurmak amaçlanmaktadır. Kellert ve Calabrese (2015) özü itibariyle Yunanca bir kelime olan "biophilia" teriminin kelime kökenini incelediğinde "bio" (hayat) ve "philia" (aşk) kelimelerinden geldiğini tespit etmiştir. Tasarım yaklaşımına adını veren terminolojiyi oluşturan kelimelerin anlamlarından yola çıkılarak "yaşam sevgisi veya canlı sistemler" tanımının türetildiği söylenebilir (Dalay, 2020). Kahn (1997) biyofiliyi, yaşam ile bağlantı kurmak ve sürdürmek amacıyla ortaya çıkan genetik temelli insan ihtiyacı ve eğilimi olarak tanımlamaktadır (Yılmaz ve Olgan, 2017). Biyofili; bireylerin fiziksel ve zihinsel sağlık, yaşamsal memnuniyet ve tatmin için kalıtımsal olarak doğaya ihtiyaç duymaları ve bu nedenle doğaya dönme, doğayla bütünleşme çabası olarak tanımlanmaktadır (Kellert, 2014; Wilson, 2016; Demirbaş ve Demirbaş, 2019). Biyofilik tasarım temel olarak, insanın yaşadığı yapılı çevreye doğal unsurların getirilmesi ve insan-doğa ilişkisinin sürdürülmesi olarak tanımlanmaktadır (Aykal ve Özil, 2021). Biyofilik tasarımın temeli doğaya has malzeme, materyal ve unsurların yaşam alanlarına taşınması ve bu materyallerle insan ilişkilerinin kuvvetlendirilmesi düşüncesine dayanmaktadır (Yurtgün, 2020).

Doğal çevre ile bağı güçlü olan yerlerin kullanıcı psikolojisi üzerinde olumlu etkileri vardır. Biyofilik tasarım desenleri stres azaltmayı, bilişsel performansı, duygu-ruh halini iyileştirmeyi ve insan vücudunu desteklemektedir (Grinde ve Grindal-Patil, 2009; Sevinç Kayıhan ve ark., 2018). Doğal elementlerle daha fazla temas ise, üretkenlikte artış, öğrenme oranlarında iyileşme, daha hızlı iyileşme süresi ve ağrı kesicilerin kullanımının azalması gibi katkılar sağlamaktadır (Bayraktaroğlu, 2014; Brown ve ark., 2013; Ikei ve ark., 2014; Nieuwenhuis ve ark., 2014; Genç vd., 2018).

İnsanların doğadan şifa bulma arzularını, doğaya dönme isteklerini ve doğa ile iç-içe olma gereksinimlerini karşılamaya peyzajın minimal bir öğesi olan bahçelerden başlanmıştır (Çalışkan ve Çelik Çanga, 2018). Botanik bahçeleri kullanıcılarına doğanın güzelliklerini sunarak bireylerin doğaya karşı pozitif tutum sergilemesine yardımcı olan, insanları diğer insanlarla, bitkilerle ve hayvanlarla bir araya getiren, eğitsel işlevleriyle 7'den 70'e farklı yaş gruplarına farklı hizmetler sunan, barındırdıkları kompozisyonlarla bireylere esin kaynağı olan bilimsel, eğitsel ve rekreasyonel işlevlere sahip özel bir bahçe kategorisidir. 
Biyofilik tasarım anlayışını en çok benimsemiş olan tasarım disiplini Peyzaj Mimarlığı olmasına karşın bu disiplinde biyofilik yaklaşımlar ile ilgili yapılan çalışma sayısı azdır. Bu çalışmada kentin içerisine doğayı getiren Nezahat Gökyiğit Botanik Bahçesi örneğinde biyofilik tasarım kriterlerinin irdelenmesi amaçlanmıştır. Bu amaç doğrultusunda çalışma alanında gözlemler yapılmış ve literatürde yer alan biyofilik tasarım ilkelerini sağlayıp sağlamadığı tartışılmıştır.

\section{MATERYAL ve YÖNTEM:}

İstanbul'un Anadolu yakasında yer alan Nezahat Gökyiğit Botanik Bahçesi yaklaşık 46 ha alan üzerinde kurulmuştur. Merkez Ada, Mesire Adası, Trakya Adası, Meşe Adası, Ertuğrul Adası, İstanbul Adası, Arboretum Adası ve Anadolu Adası olmak üzere 8 adadan oluşmaktadır. Adalar arasında bağlantılar üst geçitlerden ve menfezlerden sağlanmaktadır (Şekil 1). Altınay vd. (2011) dünyada otoyol kavşağında kurulmuş olan, ilk ve tek botanik bahçesi olduğunu ifade etmişlerdir.

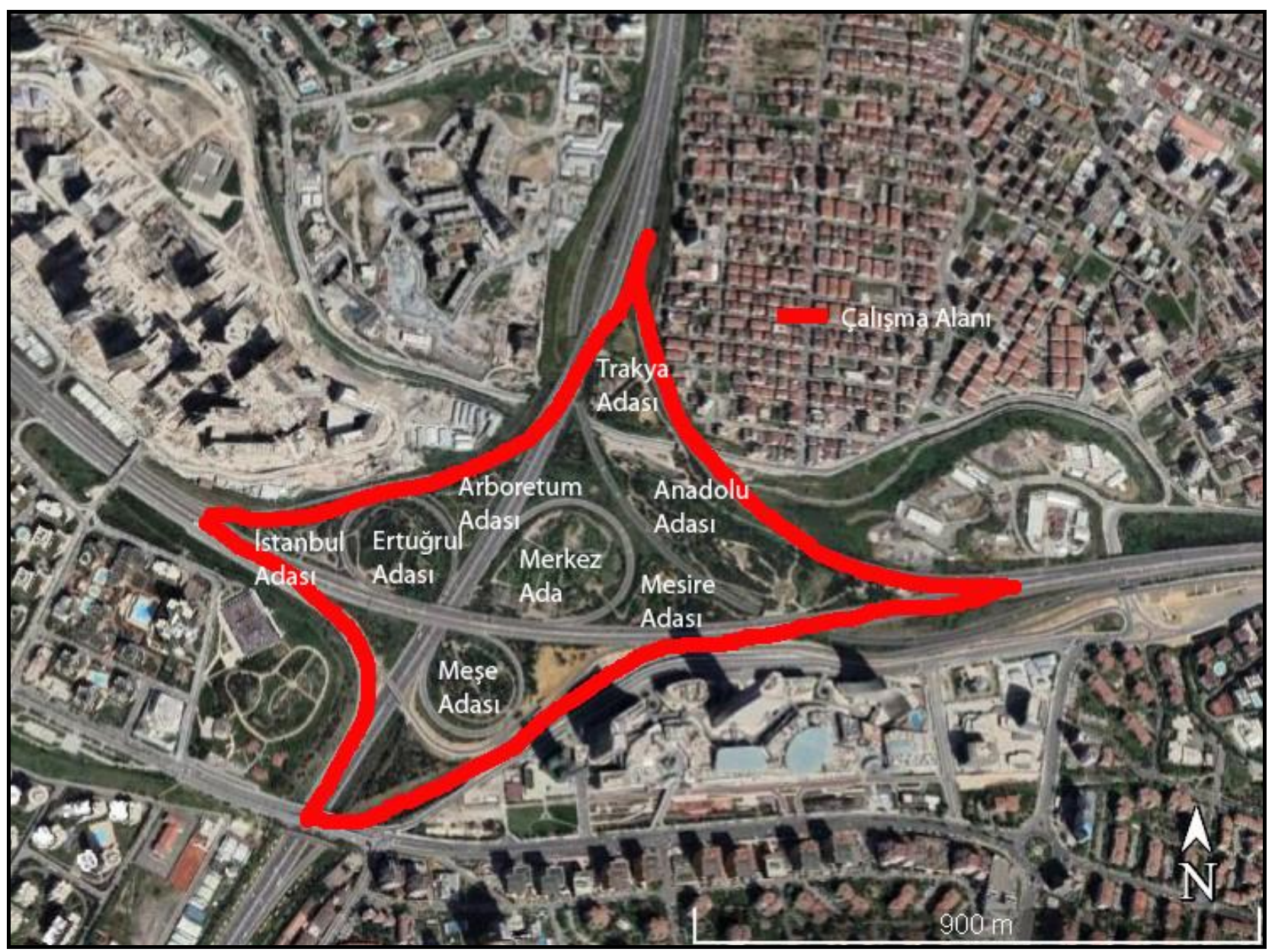

Şekil 1. Çalışma alanı

Oldukça yoğun bir kentleşmenin olduğu İstanbul kentinde adeta çölde bir vaha gibi olan botanik bahçesi kente ve kentlilere bilimsel, eğitsel ve rekreasyonel açıdan ekosistem servisleri sağlamaktadır.

Kellert (2005) biyofilik tasarım için çevresel özellikler, doğal şekiller ve formlar, doğal desenler ve süreçler, 1şık ve mekân, yer-temelli ilişkiler ve gelişmiş insan-doğa ilişkileri olmak üzere 6 adet kriter belirtmiştir (Sevinç Kayıhan ve ark., 2018). Browning vd. (2014) ise biyofilik tasarım dokusunu 3 ana başlık altında 14 kriterin yer aldığı bir biyofilik tasarım modeli kategorize etmiştir.

Evaluation of Botanical Gardens toward to the Biophilic Design Criteria: Case of Nezahat Gökyiğit Botanic Garden

Journal of Urban Academy | Volume: 14 Issue: 3 | ISSN: 2146-9229

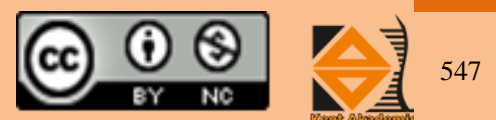


Bu çalışmada Nezahat Gökyiğit Botanik Bahçesi örneğinde Browning ve ark. (2014)'ün belirlediği biyofilik tasarımın 14 kriterinin (Tablo 1) yerinde gözlemler ve fotoğraflama tekniği kullanılarak değerlendirilmesi yapılmıştır. Daha önce yapılan çalışmalarda daha çok mimari alanda olsa da (Genç ve ark., 2018; Kaya ve Arslan Selçuk, 2018; Yurtgün, 2020) peyzaj mimarlığı alanında da (Demirbaş ve Demirbaş, 2019; Gökten ve Kelkit, 2021) bu kriterlerin kullanıldığı tespit edilmiştir.

Tablo 1. Çalışmada kullanılan biyofilik tasarım parametreleri

\begin{tabular}{|l|c|}
\hline \multirow{4}{*}{ Mekândaki Doğa } & Doğayla Görsel Bağlantı \\
& Doğayla Görsel Olmayan Bağlantı \\
& Ritmik Olmayan Görsel Uyarı \\
& Termal ve Hava Akışı Değişkenliği \\
& Suyun Varlığı \\
& Dinamik ve Dağınık Işı \\
& Doğal Sistemlerle Bağlantı \\
\hline \multirow{2}{*}{ Doğal Analojiler } & Biyomorfik Biçimler ve Dokular \\
& Doğayla Malzeme Bağlantısı \\
& Karmaşa ve Düzen \\
\hline \multirow{2}{*}{ Mekânın Doğallığı } & Olasılık/Manzara \\
& Siğınak \\
& Gizem \\
& Risk/Tehlike \\
\hline
\end{tabular}

\section{BULGULAR:}

\section{Biyofilik Tasarım Parametreleri Doğrultusunda Elde Edilen Bulgular}

Çalışmanın bu bölümünde, çalışma alanı biyofilik tasarım kriterleri doğrultusunda irdelenmiştir. Nezahat Gökyiğit Botanik Bahçesi doğayla iletişimi kopan kent insanının doğayla tekrar bağ kurması noktasında önemli bir paya sahiptir.

Mekândaki doğa parametresi bağlamında çalışma alanı doğayla görsel bağlantı, doğayla görsel olmayan bağlantı, ritmik olmayan görsel uyarı, termal ve hava akışı değişkenliği, suyun varlığı, dinamik ve dağınık 1şık, doğal sistemlerle bağlantı olmak üzere 7 kriter kapsamında değerlendirilmiştir.

Çalışma alanı içerisinde kullanıcıların doğayla görsel bağlantı kurmasını sağlayan çok sayıda öge mevcuttur. Mevsimler boyunca farklı manzaralar sunan bitkilerin varlığı, alan içerisinde farklı adalar içerisinde kurgulanan su ögeleri ve hayvanların varlığı alan kullanıcılarının doğayla görsel bağlantı kurmasını sağlayan unsurlardır (Şekil 2). 

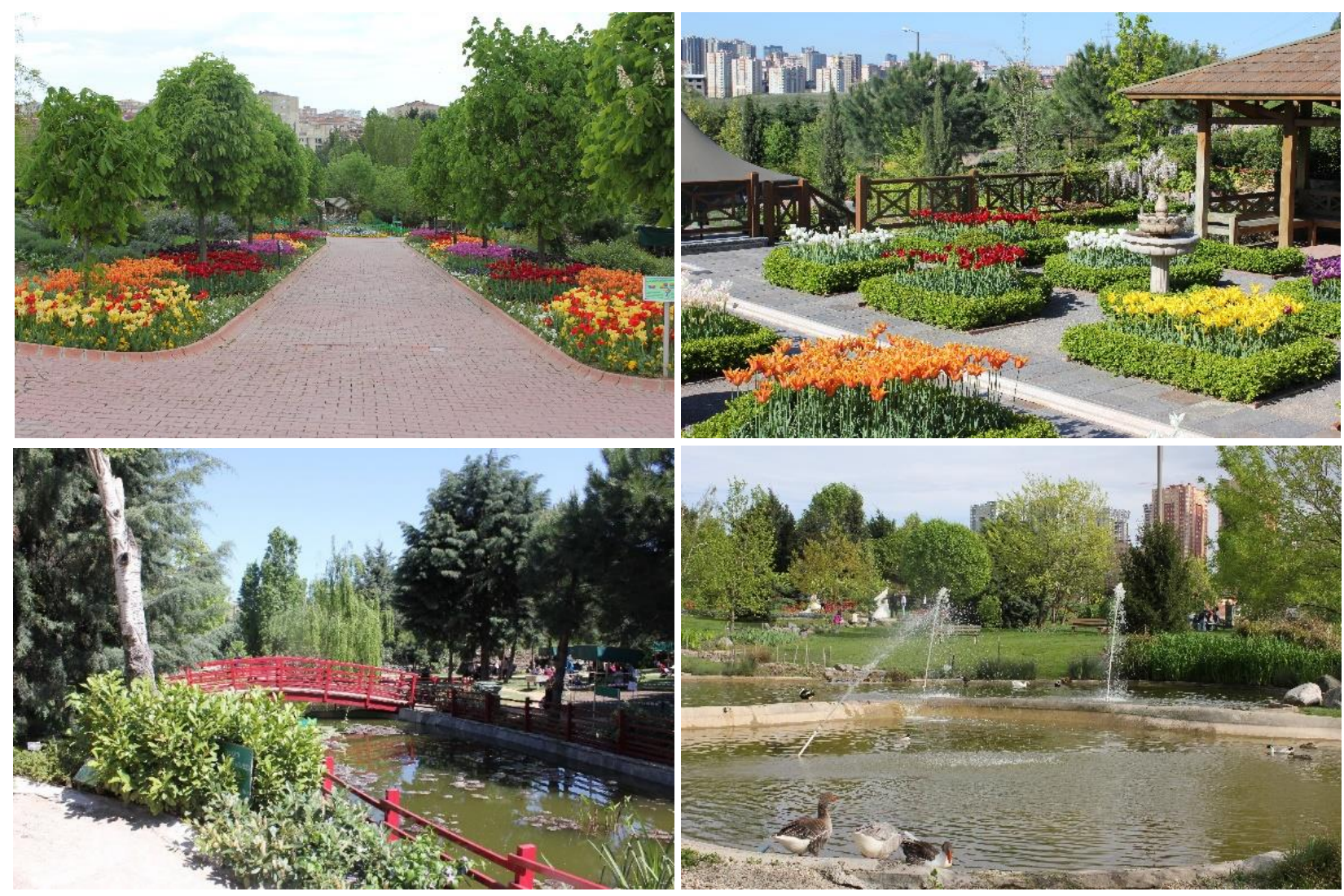

Şekil 2. Çalışma alanında kullanıcıların doğayla görsel bağlantı kurmasını sağlayan unsurlar

Doğayla görsel olmayan bağlantı bağlamında, çalışma alanı içerisinde kullanılan hareketli suların sesleri, İstanbul Adası'ndaki kameriyelerdeki hoparlörlerden gelen kuş sesleri ve Merkez Ada ve Mesire Adası'nda yer alan ördeklerin sesleri ve yine bahçede kullanılan bitkilerden gelen kokular kullanıcıların doğayla görsel olmayan bağlantı kurmasını sağlayan unsurlardır (Şekil 3). 

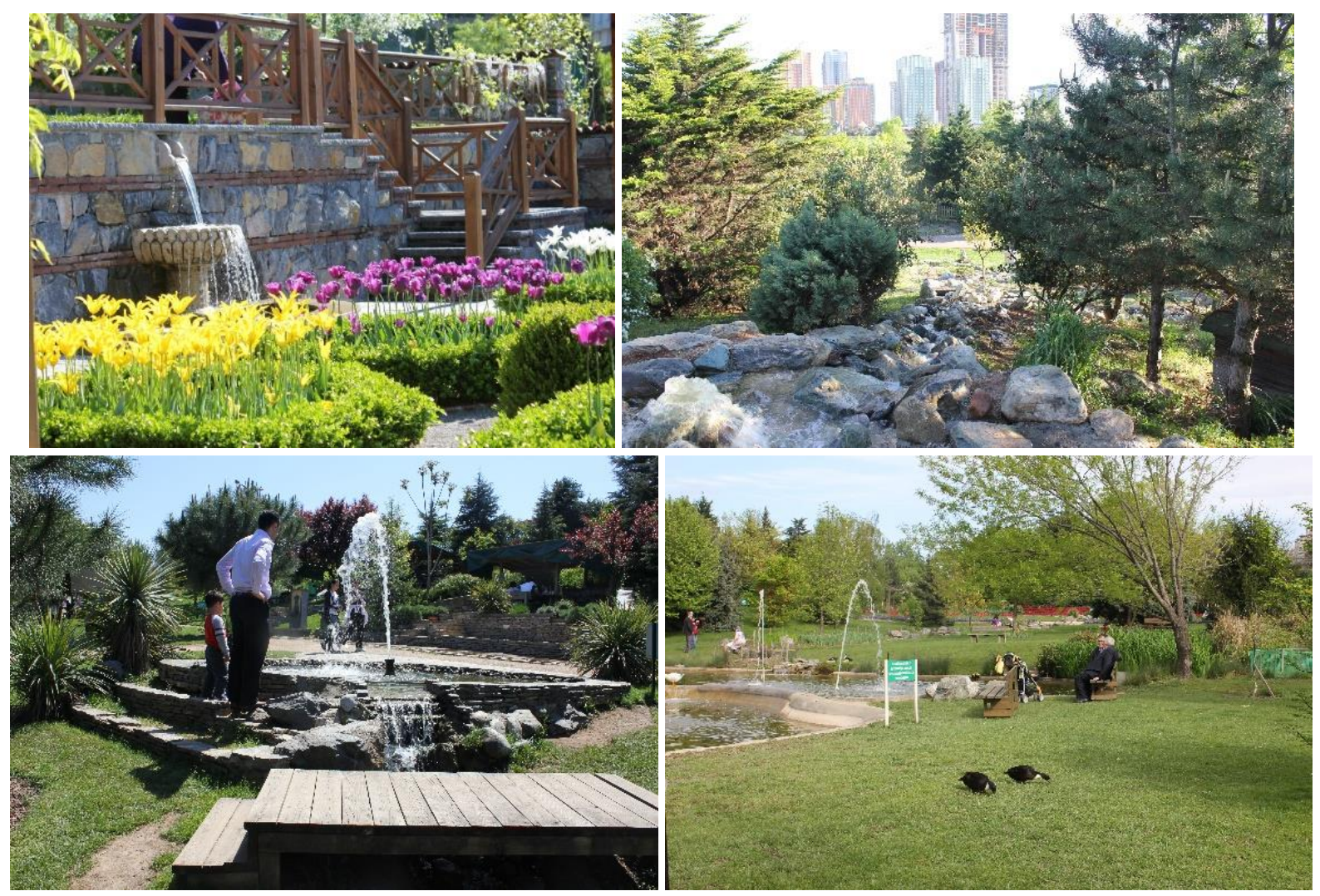

Şekil 3. Çalışma alanında kullanıcıların doğayla görsel olmayan bağlantı kurmasını sağlayan hareketli sular ve ördekler

Çalışma alanı içerisinde bulunan ağaçlar, çalılar, çiçekler ve çimlerin hafif bir esintiyle hareket etmesi ve su yüzeylerinin dalgalanması ritmik olmayan duyusal uyaranların varlığını göstermektedir. Çevresinde yoğun bir yapılaşma ve yüksek katı binalar olsa da çalışma alanının toğoğrafik yapısı ve yoğun yeşil dokusu temiz hava akımını sağlamaktadır. Ayrıca çalışma alanı içerisinde bulunan su yüzeylerinin çevresi ve bitkilerle oluşturulan gölgeli oturma alanları termal açıdan mikroklimatik ortamlardır (Şekil 4).
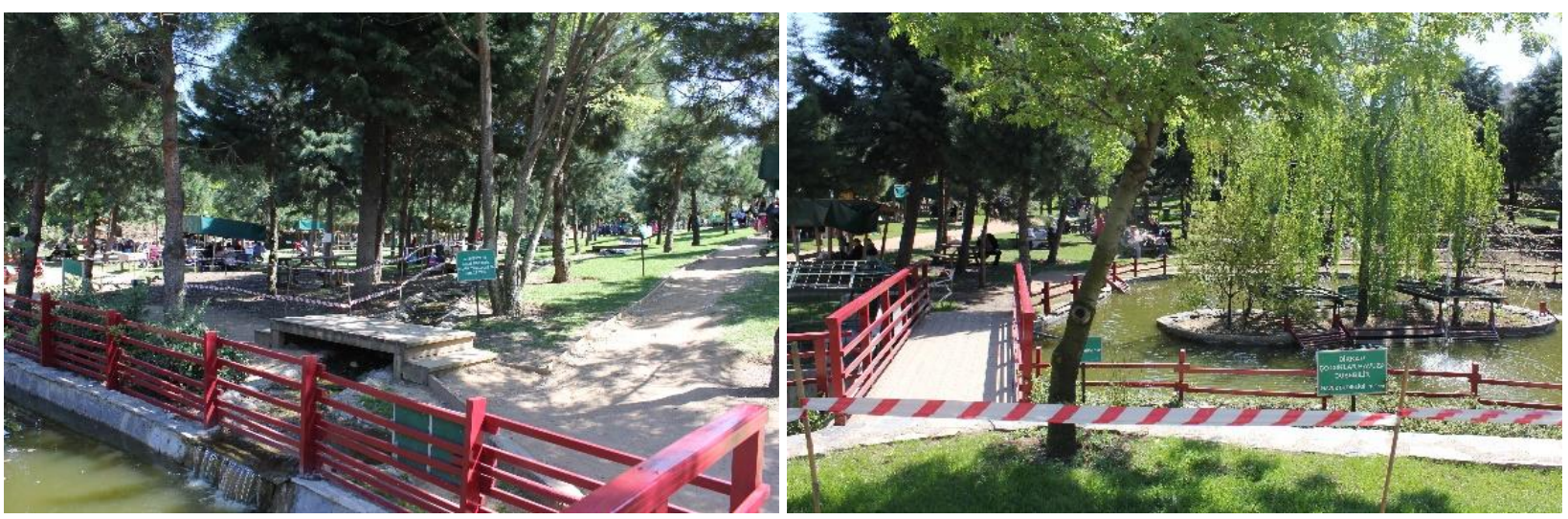

Şekil 4. Çalışma alanında bulunan su kenarı ve ağaç altı oturma alanları

Çalışma alanı içerisinde, Meşe Adası'nda yağmur sularının toplandığı, Anadolu Adası'nda nilüfer havuzlarının yer aldığı̆, İstanbul Adası'nda İstanbul Boğazı'nın simgelendiği, Merkez Ada'da ve Arboretum Adası'nda göletlerin yer

Evaluation of Botanical Gardens toward to the Biophilic Design Criteria: Case of Nezahat Gökyiğit Botanic Garden

Journal of Urban Academy | Volume: 14 Issue: 3 | ISSN: 2146-9229

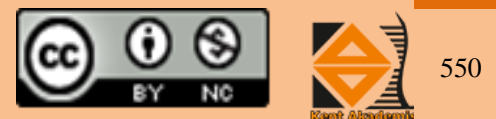


aldığ çok sayıda su ögesi mevcuttur. Kullanıcılar suyun hem dokunsal hem işitsel hem de görsel özelliğinden faydalanabilmektedir (Şekil 5).
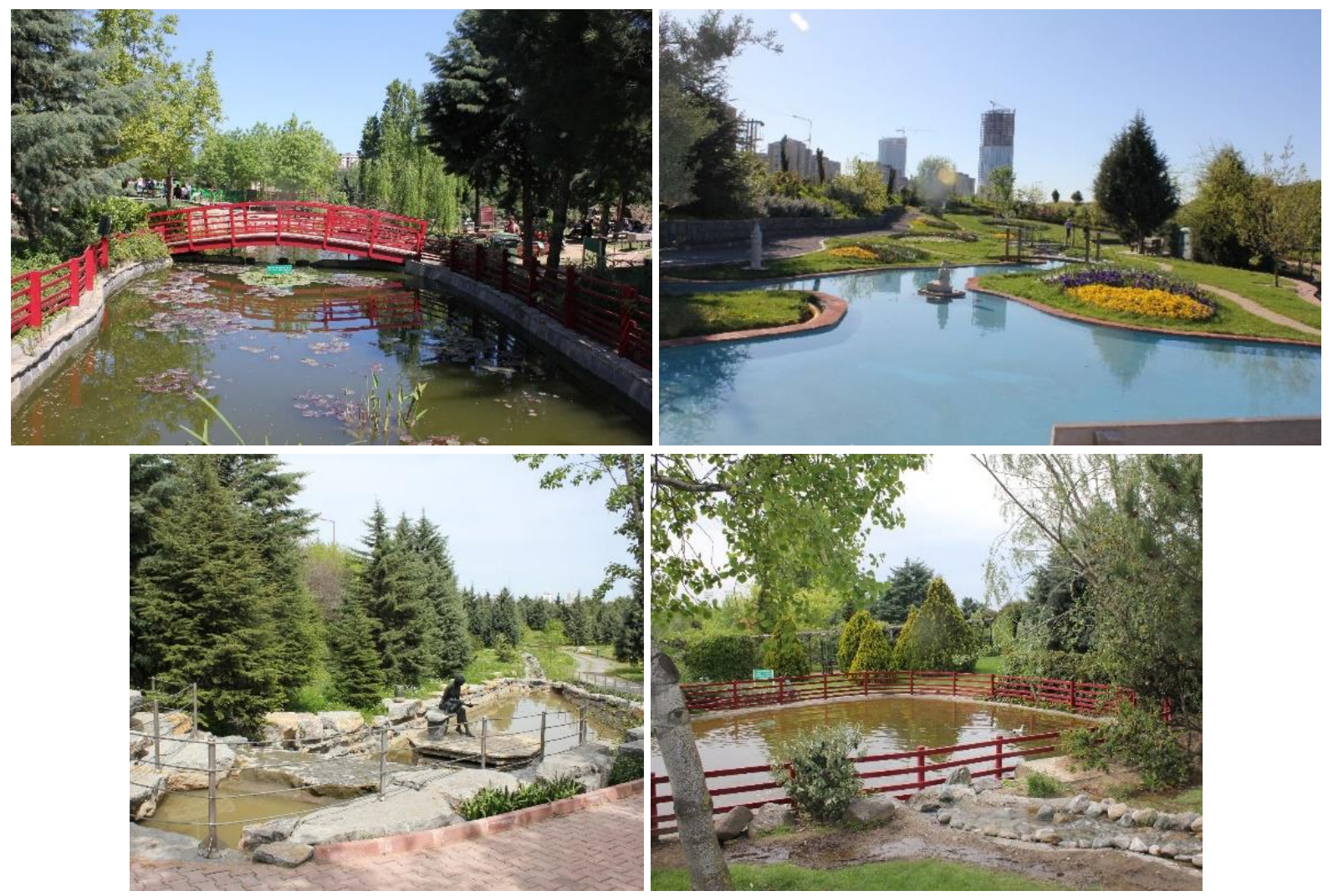

Şekil 5. Çalışma alanı içerisinde bulunan su ögeleri

Çalışma alanı içerisinde yer alan geniş çim alanlar üzerinde kullanıcılar ışığı doğrudan, ağaçların altında gölge alanlarda ise dinamik ve dağınık ışığı deneyimleyebilmektedir. Çalışma alanında 1şık gölge oyunları ile doğada meydana gelen aydınlatma koşulları da taklit edilmiştir. Doğal sistemlerle bağlantı bağlamında kullanıcılar çalışma alanı içerisinde mevsimler değişimleri gözlemleme imkânı bulabilmektedir (Şekil 6).
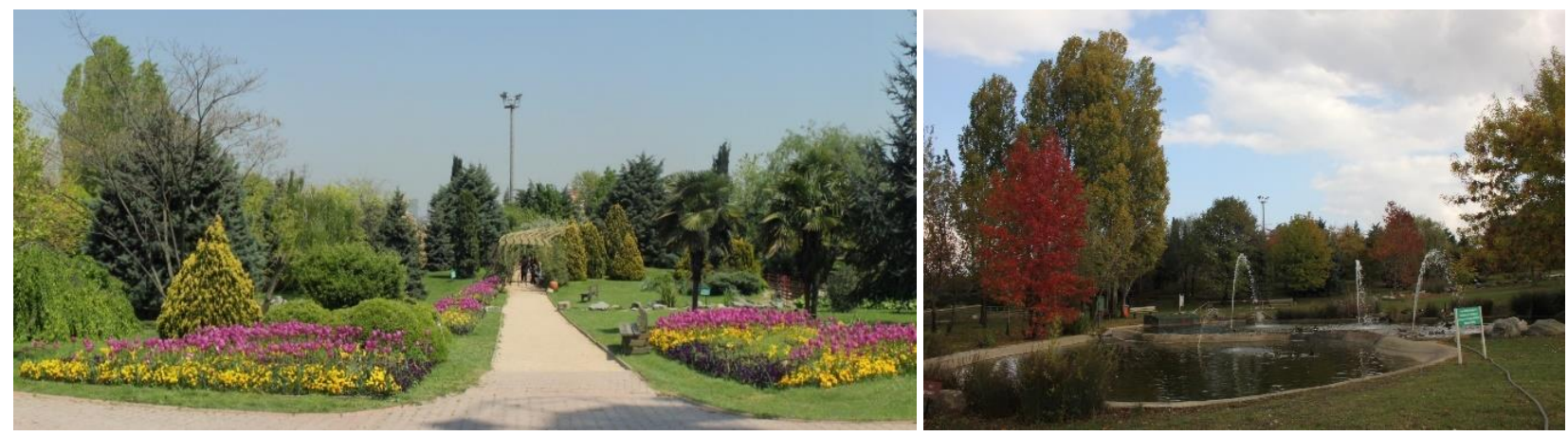

Şekil 6. Çalışma alanından ilkbahar ve sonbahar mevsimine ilişkin birer görüntü

Çalışma alanı doğal analojiler bağlamında biyomorfik biçimler ve dokular, doğayla malzeme bağlantısı ve karmaşa ve düzen olmak üzere 3 kriter kapsamında değerlendirilmiş̧ir.

Evaluation of Botanical Gardens toward to the Biophilic Design Criteria: Case of Nezahat Gökyiğit Botanic Garden

Journal of Urban Academy | Volume: 14 Issue: 3 | ISSN: 2146-9229

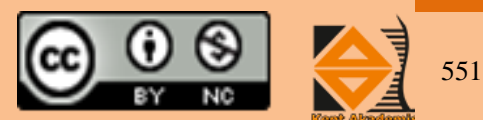


Çalışma alanı içerisinde doğadan öykünerek tasarlanmış biyomorfik biçimlere ve dokulara rastlamak mümkündür. Örneğin alan içerisinde oluşturulan yaya akslarında doğal formların kullanılmasının yanı sıra Merkez Ada'da yer alan kaya bahçesi ve kaya çatlağı bahçesinde de bu formları görmek olasıdır (Şekil 7).
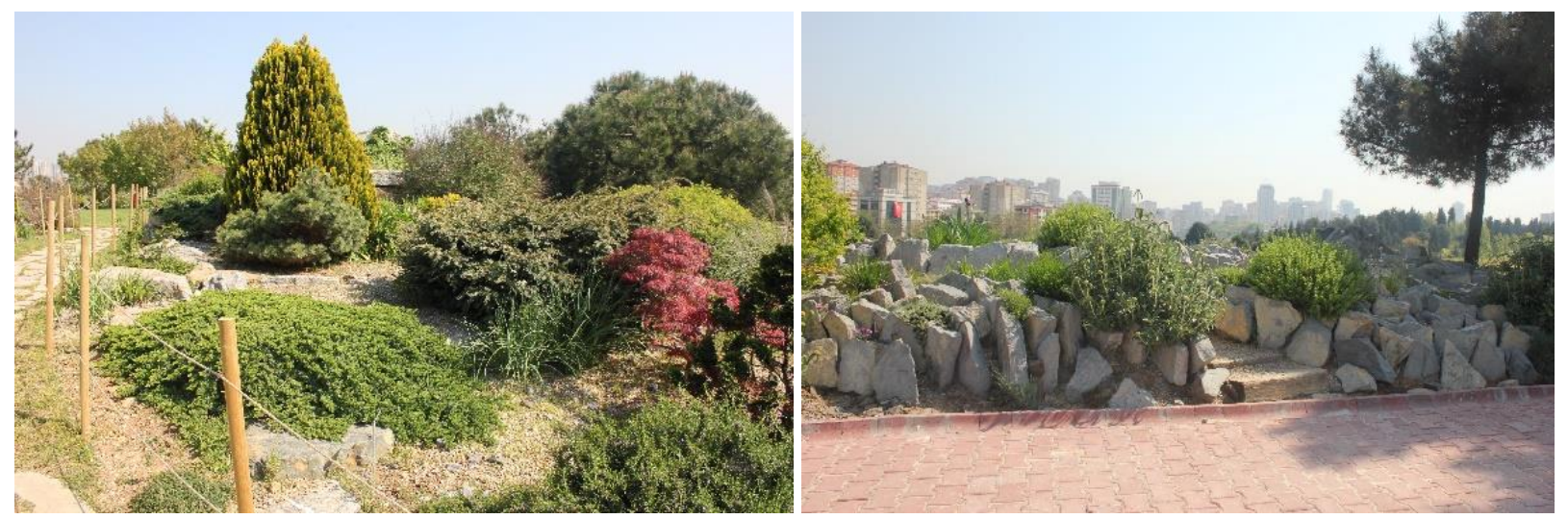

Şekil 7. Çalışma alanı içerisinde yer alan kaya bahçesi ve kaya çatlağı bahçesi örnekleri

Çalışma alanı içerisinde doğayla malzeme bağlantısı yer yer sağlanmış olsa da bu görsel bağlantının koptuğu noktalar mevcuttur (Şekil 8). Ayrıca çalışma alanı içerisinde çocukların doğayı deneyimleyebileceği, mental ve fiziksel gelişimini destekleyecek doğal malzemelerle tasarlanmış çocuk oyun alanı, farklı yaş gruplarının doğaya ilgilerini arttırmak amacıyla kurgulanmış oyunlar (teşhis yolu oyunu) ve yine her yaş grubu için kurgulanmış 'Meşemi Buluyorum' oyunlarının olduğu tespit edilmiştir. Bahçede 'Bahçıvan Çocuklar', 'Faydalı Bitkiler', 'Doğa Bilginleri' gibi çeşitli projeler de yürütülmektedir (Şekil 9). 

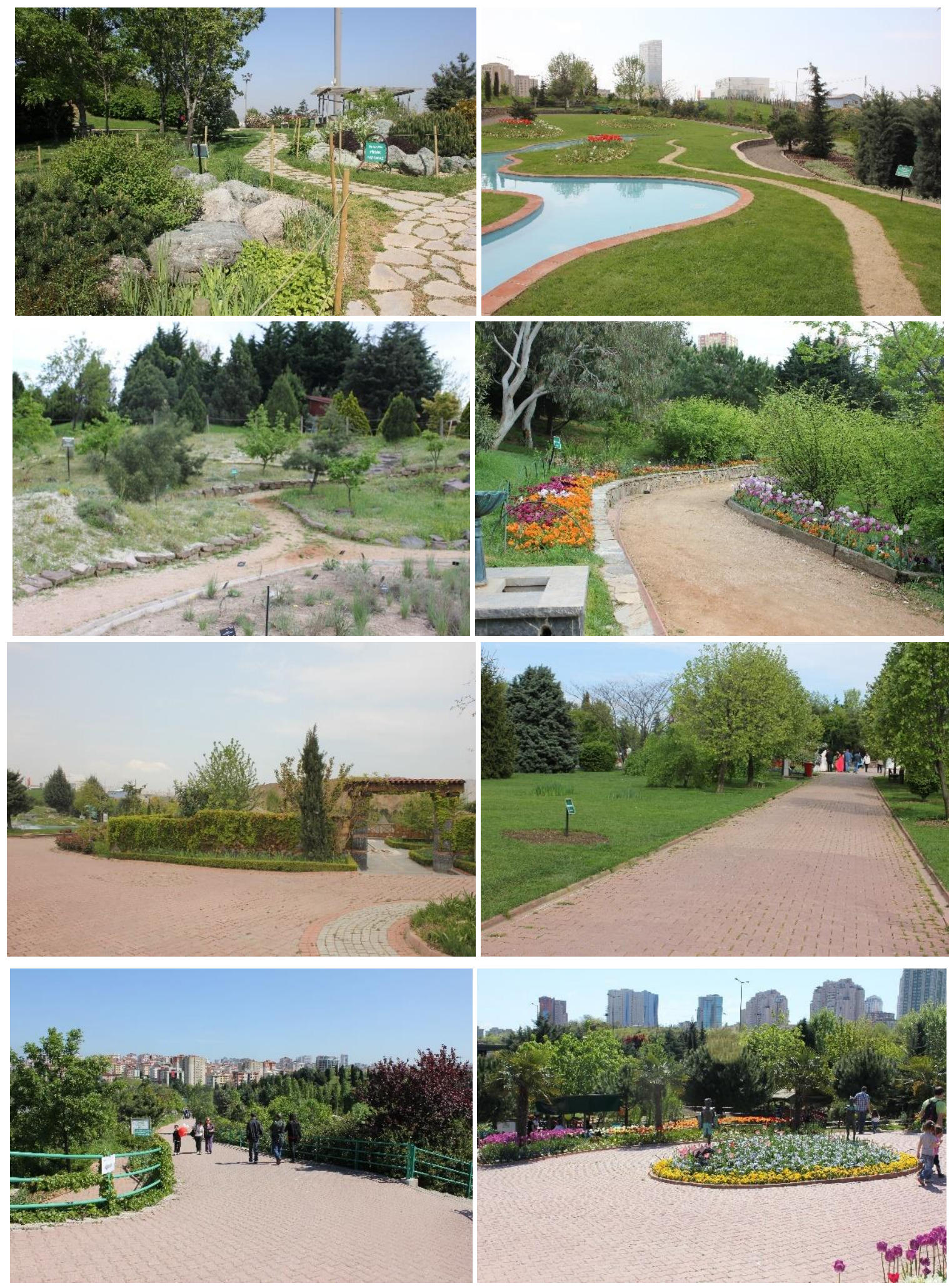

Şekil 8. Çalışma alanında kullanılan doğal malzemeler ve doğal olmayan malzemeler (İlk 4 görselde doğal malzemeler, diğer görsellerde doğal olmayan malzemeler kullanılmıştır)

Evaluation of Botanical Gardens toward to the Biophilic Design Criteria: Case of Nezahat Gökyiğit Botanic Garden

Journal of Urban Academy | Volume: 14 Issue: 3 | ISSN: 2146-9229

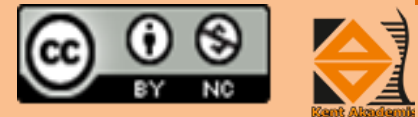



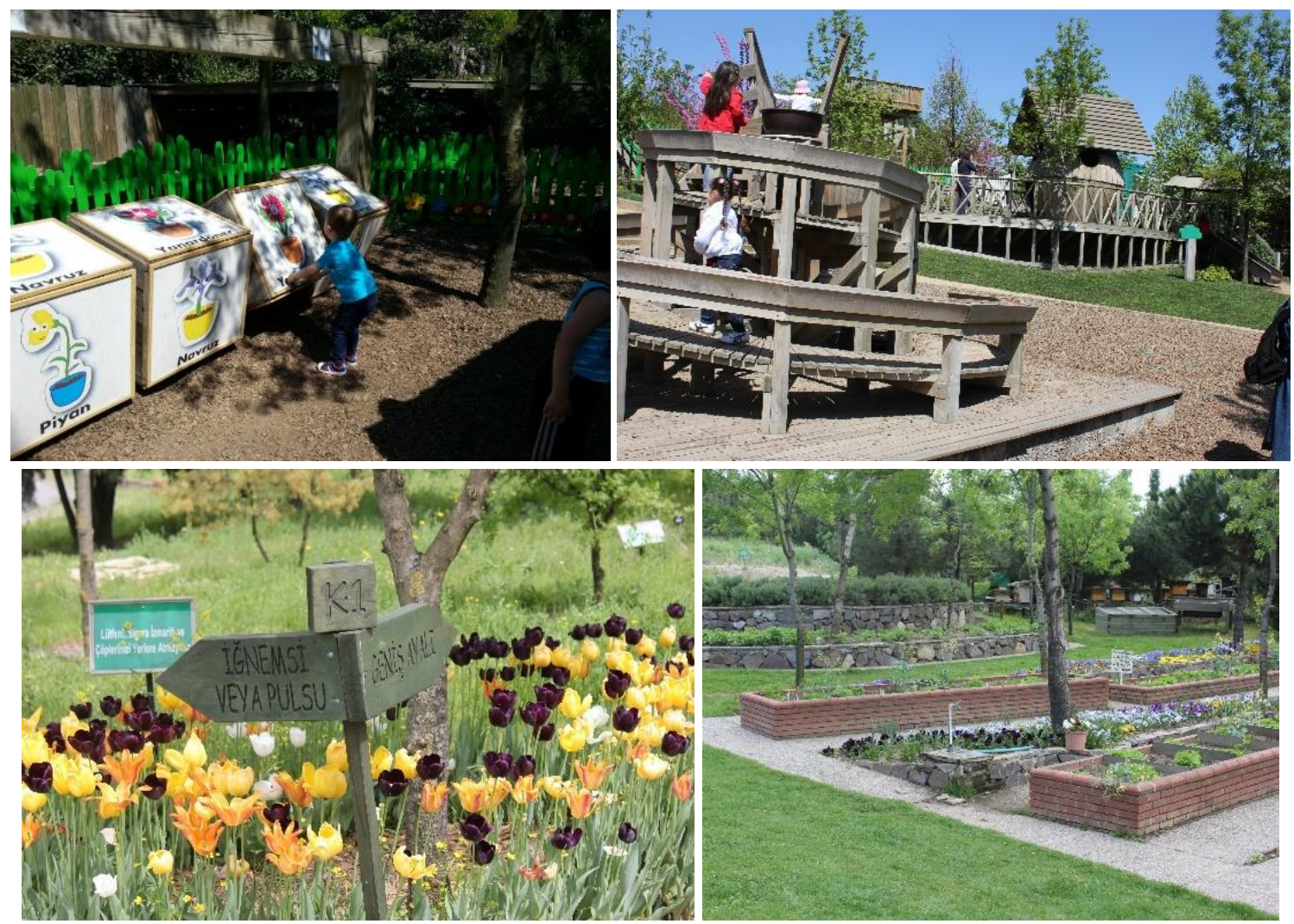

Şekil 9. Çalışma alanında yer alan çocuk oyun alanı, teşhis yolu oyunu ve bahçıvan çocuklar projesinin gerçekleştirildiği alan

Karmaşa ve düzen ilkesi bağlamında çalışma alanı içerisinde tüm mekanlar hiyerarşik bir düzen içerisinde kurgulanmıştır.

Mekanın doğallığı bağlamında ise çalışma alanı olasılık/manzara, sığınak, gizem ve risk/tehlike olmak üzere 4 kriter kapsamında değerlendirilmiştir.

Çalışma alanının tümü manzara değeri yüksek bir potansiyele sahiptir. Ancak bu manzara güzelliğini daha iyi algılayabilmek gözlemleyebilmek için çalışma alanı içerisinde seyir noktaları oluşturulmuştur (Şekil 10).

Evaluation of Botanical Gardens toward to the Biophilic Design Criteria: Case of Nezahat Gökyiğit Botanic Garden

Journal of Urban Academy | Volume: 14 Issue: 3 | ISSN: 2146-9229

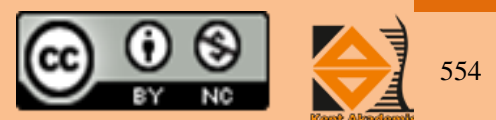



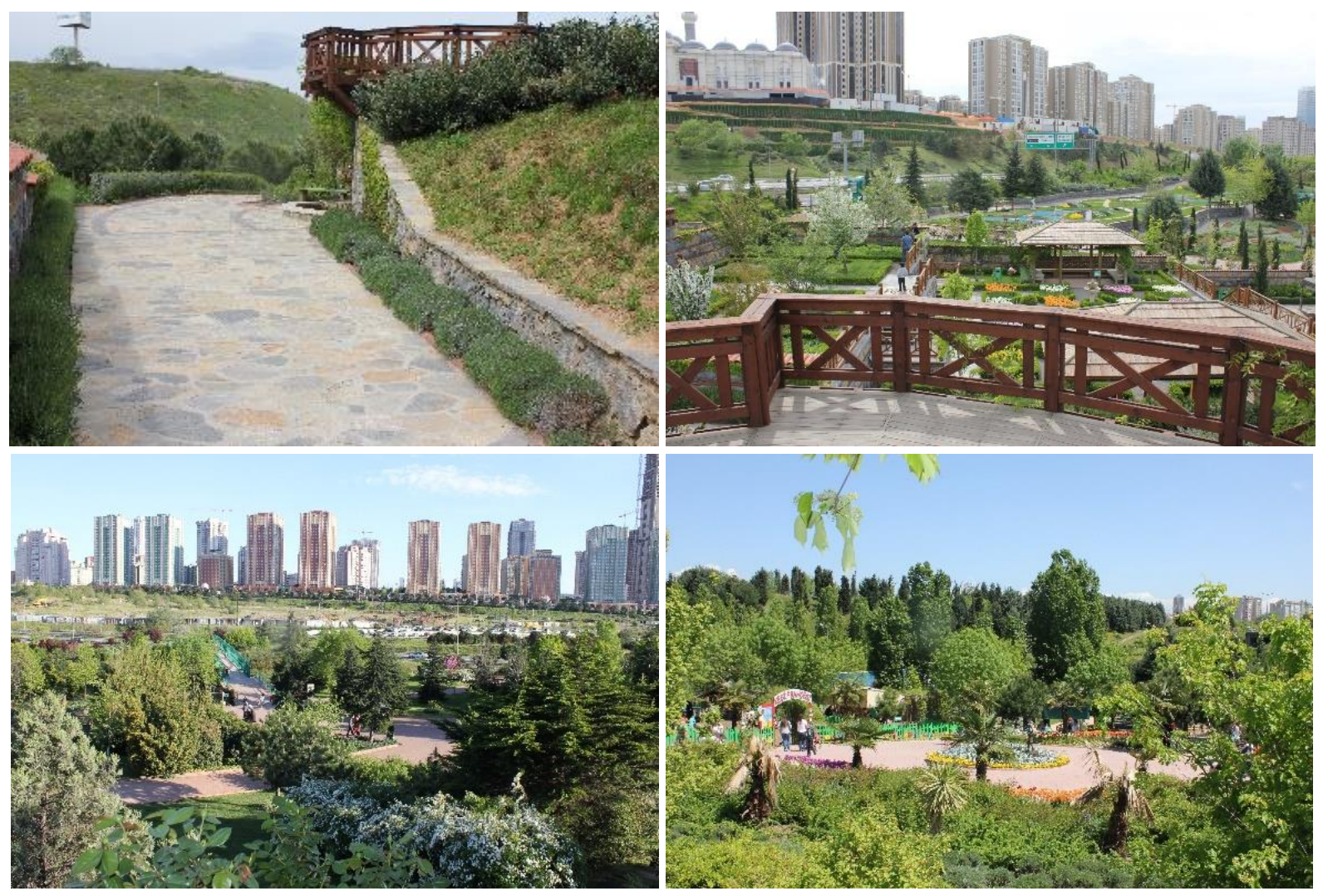

Şekil 10. Çalışma alanı içerisinde kurgulanan seyir noktaları

Sığınma ilkesi bağlamında çalışma alanı içerisinde kullanıcıların isterse tek başına kalabileceği isterse diğer bireylerle birlikte zaman geçirebileceği yarı kapalı oturma alanları yer almaktadır (Şekil 11).
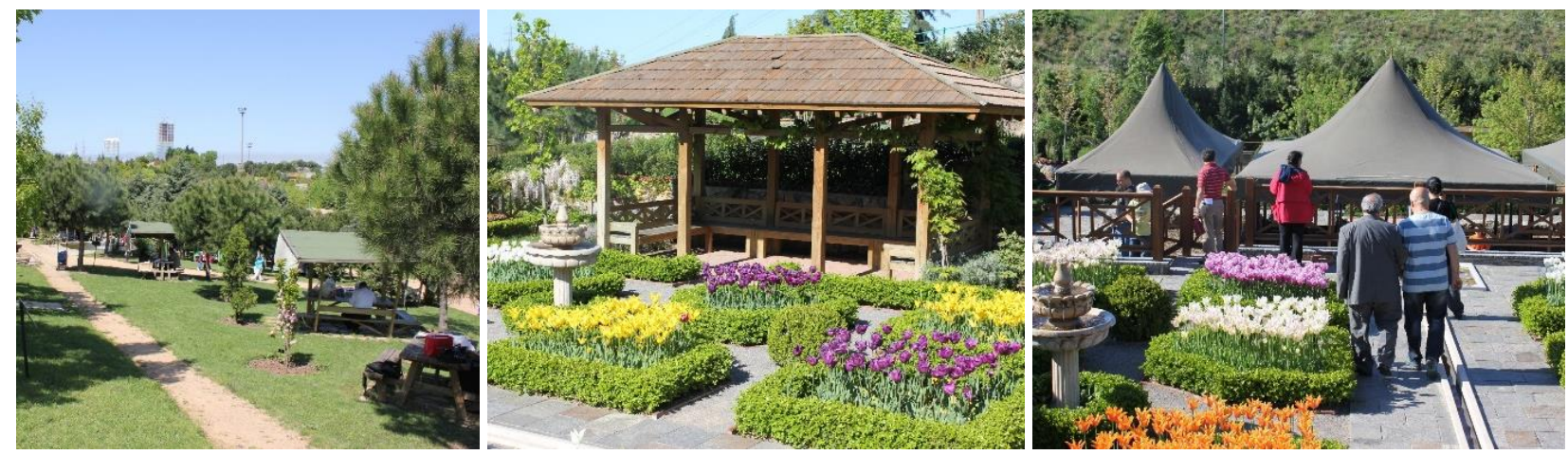

Şekil 11. Çalışma alanı içerisinde yer alan oturma dinlenme alanları

Çalışma alanı içerisinde kurgulanan bitkisel kompozisyonlarla görsel engeller oluşturularak, kullanıcıların bu engellerin arkasındakilerini merak etmeleri sağlanarak gizem ilkesinin kurgulandığı tespit edilmiştir (Şekil 12).

Evaluation of Botanical Gardens toward to the Biophilic Design Criteria: Case of Nezahat Gökyiğit Botanic Garden

Journal of Urban Academy | Volume: 14 Issue: 3 | ISSN: 2146-9229

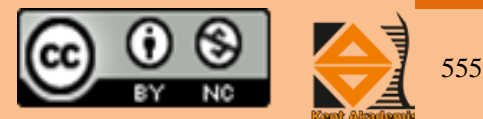




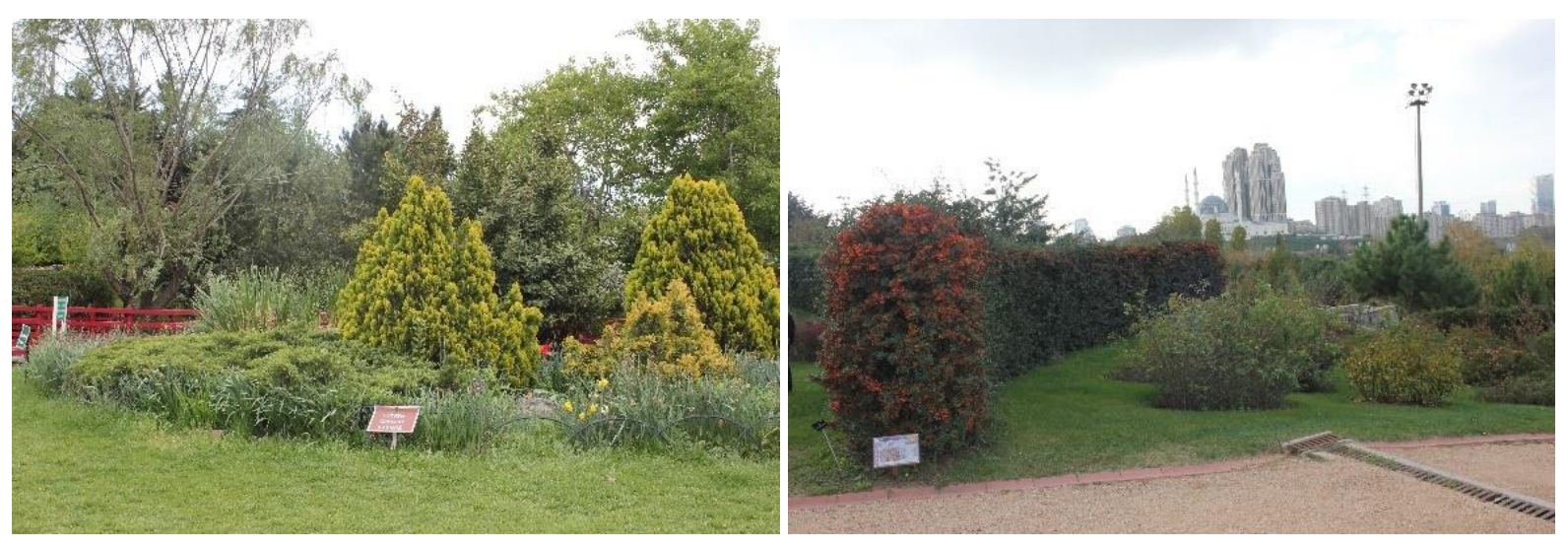

Şekil 12. Çalışma alanı içerisinde kompoze edilen bitkilendirme tasarımı örnekleri

Risk/tehlike ilkesi bağlamında tehlike oluşturabilecek alanlarda (su kenarları, yüksek alanlar) güvenlik önlemleri alınmış ve uyarı levhaları ile tehlikelerin kullanıcılara hatırlatıldığı tespit edilmiştir (Şekil 13).
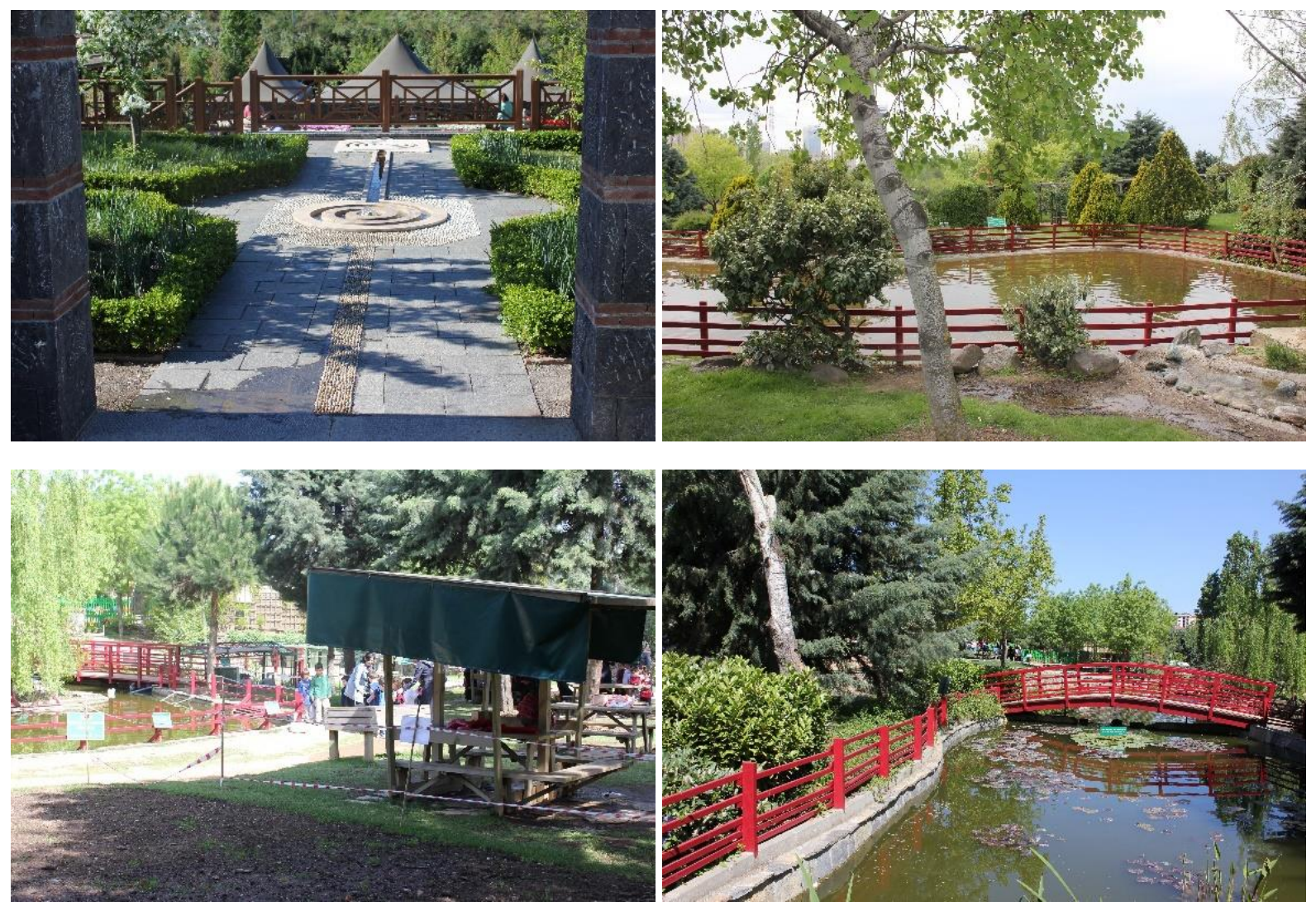

Şekil 13. Çalışma alanı içerisinde riskleri önlemek amacıyla alınan önlem örnekleri

\section{TARTIŞMA ve SONUÇ:}

Kent yaşamı insanların mental ve fiziksel sağlığı üzerinde olumsuz etkiler oluşturmaktadır. Bu olumsuz etkiler de bireylerin hem günlük yaşamına hem de iş yaşamına yansımakta ve her geçen gün mutsuz, huzursuz ve iş ortamında verimsiz bireylerin sayısı artmaktadır. Yapılan birçok çalışmada yeşili görmenin bile bireyler üzerinde olumlu

Evaluation of Botanical Gardens toward to the Biophilic Design Criteria: Case of Nezahat Gökyiğit Botanic Garden

Journal of Urban Academy | Volume: 14 Issue: 3 | ISSN: 2146-9229

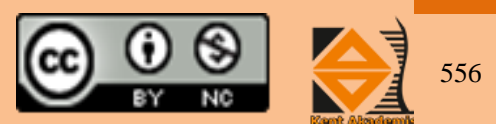


sonuçlar oluşturduğu ifade edilmiştir. Önemli bir kentsel yeşil alan botanik bahçeleri de insanlara doğanın güzelliklerini sunan, nesli tükenme tehlikesi altındaki bitkilerin korunduğu ve farklı yaş gruplarına eğitsel faaliyetler sunan özel bahçelerdir.

Birçok araştırmacıya (Engleson ve Yockers, 1994; Chawla 1999; Wells ve Lekies, 2006; Chawla, 2007; Samways, 2007) göre, bireylerin doğa ile bağının azalması ya da tamamen kopması, onların yaşamları boyunca doğayı korumak ve doğaya saygılı davranmak konularında özensiz olabileceklerine işaret etmektedir (Y1lmaz ve Olgan, 2017). Biyofilik tasarımda da doğadan kopan bireylerin yeniden ilişkilerinin kurulması ve sürdürülmesi hedeflenmektedir. Nezahat Gökyiğit Botanik Bahçesi doğayla iletişimi kopan kent insanının doğayla tekrar bağ kurması noktasında önemli bir paya sahiptir.

Çalışma alanı biyofilik tasarımın 14 kriteri bağlamında değerlendirildiğinde, çalışma alanının bu kriterlerden sadece 1 tanesini (doğayla malzeme bağlantısı) sağlamada belirli bir oranda eksik kaldığı söylenebilir (Tablo 2). Çalışma alanı mevcut faunası, florası ve aurasıyla, rekreasyonel ve eğitsel açıdan sunduğu aktiviteleriyle kullanıcılarına kentsel yaşamın baskılarından uzak bir ortam sunmakta, sosyalleşme imkânı sağlamakta ve ruhsal açıdan bireylerin yenilenmesine ve iyileşmesine katkı sağlamaktadır. Ayrıca 15 milyondan fazla insanın yaşadığı İstanbul kentinde insanları doğayla buluşturan böyle bir değerin olması büyük bir önem arz etmektedir.

Tablo 2. Çalışma alanının sağladığı biyofilik tasarım kriterleri (**: Sağlamakta, *: Kısmen sağlamakta)

\begin{tabular}{|c|c|}
\hline BIYYOFİLİK TASARIM KRİTERLERİ & $\begin{array}{l}\text { Çalışma Alanının } \\
\text { Sağladığı Kriterler }\end{array}$ \\
\hline \multicolumn{2}{|l|}{ Mekândaki Doğa } \\
\hline Doğayla Görsel Bağlantı & $* *$ \\
\hline Doğayla Görsel Olmayan Bağlantı & $* *$ \\
\hline Ritmik Olmayan Görsel Uyarı & $* *$ \\
\hline Termal ve Hava Akışı Değişkenliği & $* *$ \\
\hline Suyun Varlı̆ğ & $* *$ \\
\hline Dinamik ve Dağınık Işık & $* *$ \\
\hline Doğal Sistemlerle Bağlantı & $* *$ \\
\hline \multicolumn{2}{|l|}{ Doğal Analojiler } \\
\hline Biyomorfik Biçimler ve Dokular & $* *$ \\
\hline Doğayla Malzeme Bağlantısı & $*$ \\
\hline Karmaşa ve Düzen & $* *$ \\
\hline \multicolumn{2}{|l|}{ Mekânın Doğallığı } \\
\hline Olasılık/Manzara & $* *$ \\
\hline Sığınak & $* *$ \\
\hline Gizem & *** \\
\hline Risk/Tehlike & $* *$ \\
\hline
\end{tabular}

Chawla, (2006) çocuklara doğa sevgisi aşılamak, onların doğayla etkileşimlerini ve doğaya yakınlıklarını artırmak ya da çocukları doğa ile ilişkili herhangi bir uyarana karşı verilebilecekleri olumsuz tepkilerden ve korkulardan korumak için, onlara doğada keşif yapma ve farklı deneyimler kazanma firsatlarının sunulması önem arz ettiğini ifade etmiştir (Sobel, 2008; Yılmaz ve Olgan, 2017). Nezahat Gökyiğit Botanik Bahçesi özellikle çocuklar için doğal malzemelerin kullanıldığı keşif bahçesi, bambulu çit ve çocukların doğayı tanımaları ve keşfetme isteklerinin giderilmesine yardımcı olan 'Teşhis Oyunu Yolu' ve 'Meşemi Buluyorum' oyunuyla ve okul gruplarına yönelik eğitim programları ile çocukların doğayla etkileşimlerine önemli katkılar sağlayan bir bahçedir. Bahçe içerisinde kullanıcılar kümes hayvanlarını da görme imkanına sahiptir. Ancak bahçe içerisinde çocukların hayvanlarla temas haline geçebilecekleri tavşan, sincap gibi türlere de yer verilerek çocukların hem hayvan sevgisini kazanmasına hem de korkularını yenmesine katkı sağlanacağı düşünülmektedir. 
Bahçede doğal malzemelerle bağlantı noktasında bazı mekanlarda kullanılan parke taşları yerine toprak tonlarında doğal malzemelerin kullanılması bu noktadaki eskiliği gidermede etkili olacaktır.

Aslında çok eski zamanlardan beri Peyzaj Mimarlığı disiplininde benimsenen ancak kavramsal olarak yeni bir yaklaşım olan biyofilik tasarımlar sayesinde insanların daha mutlu ve sağlıklı olacağı düşünülmektedir. Bu noktada birer sağlık bahçeleri olan botanik bahçeleri de sunduğu etkinliklerle, mevcut mekan kurguları ve bitkilendirme tasarımlarıyla etkili alanlardır. Zengin biyoçeşitliliğe sahip ülkemizde nesli tükenme tehlikesi altındaki türlerin korunup gelecek nesillere aktarılacağı, doğa sevgisinin ve kendinin de doğanın bir parçası olduğu bilincinin aşılanacağı, doğal hayatın deneyimlenebileceği botanik bahçeleri sayısının arttırılması gerekmektedir. Ayrıca kentlerimizde kurgulanan en küçük cep parklardan üst ölçekteki yeşil alan kullanımlarına kadar biyofilik tasarım kriterlerinin yaygınlaştırılarak benimsenmesinin gerektiği düşünülmektedir.

\section{Etik Standart ile Uyumluluk}

Çıkar Çatışması: Yazarlar herhangi bir çıkar çatışmasının olmadığını beyan eder.

Etik Kurul İzni: Bu çalı̧̧ma için etik kurul iznine gerek yoktur.

Finansal Destek: Bu çalışma için herhangi bir finansal destek alınmamıştır.

\section{KAYNAKÇA:}

\section{Makaleler}

Aykal, F.D., \& Erbaş Özil, M. (2021). Biyofilik Tasarımın Diyarbakır Geleneksel Konutlarında Araştırılması. Mimarlık Bilimleri ve Uygulamaları Dergisi (MBUD), 6(1), 45-58.

Brown, D.K., Barton, J.L., \& Gladwell, V.F. (2013). Viewing Nature Scenes Positively Affects Recovery of Autonomic Function Following Acute Mental Stress. Environmental Science and Technology, 47(11), 5562-5569.

Chawla, L. (1999). Life Paths into Effective Environmental Action. The Journal of Environmental Education, 31(1), $15-26$.

Chawla, L. (2006). Learning to Love the Natural World enough to Protect it. Barn, 2, 57-78.

Chawla, L. (2007). Childhood Experiences Associated with Care for the Natural World: A Theoretical Framework for Empirical Results. Children Youth and Environments, 17(4), 144-170.

Çalışkan, H., \& Çelik Çanga, A. (2018). Şifa Bahçeleri ve Turizmdeki Yeri. Uluslararası Turizm, İşletme, Ekonomi Dergisi, 2(2), 541-548.

Dalay, D. (2020). The Impact of Biophilic Design Elements on the Atmospheric Perception of The Interior Space. International Journal of Landscape Architecture Research, 4(2), 4-20.

Demirbaş, G.U., \& Demirbaş Ö.O. (2019). Biyofilik Tasarım Kapsamında Peyzaj Mimarlığı ve İç Mimarlık Arakesiti: Eğitim Programlarının Karşılıklı Değerlendirilmesi. Türkiye Peyzaj Araştırmaları Dergisi, 2(2), 50-60.

Genç, G., Selçuk, S.A., \& Beyhan, F. (2018). Biyofilik Kavramının Tarihi Binalar Bağlamında Değerlendirilmesi: Tokat Mustafa Ağa Hamamı. Uluslararası Sosyal Araştırmalar Dergisi, 11(58), 363-372.

Grinde, B. \& Grindal-Patil, G.G. (2009). Biophilia: Does Visual Contact with Nature Impact on Health and WellBeing? International Journal of Environmental Research and Public Health, 6(9), 2332-2343.

Gökten, İ. \& Kelkit, A. (2021). Ankara İmrahor Vadisi ve İncesu Deresinin biyofilik tasarım yaklaşımı içinde değerlendirilmesi. ÇOMÜ Ziraat Fakültesi Dergisi, 9(1), 71-78. 
Ikei, H., Komatsu, M., \& Song, C.R. (2014). The Physiological and Psychological Relaxing Effects of Viewing Rose Flowers in Office Workers. Journal of Physiological Anthropology, 33, 1-5.

Kahn, P.H. (1997). Developmental Psychology and the Biophilia Hypothesis: Children's Affiliation with Nature. Developmental Review, 17(1), 1-61.

Kaya, H., \& Arslan Selçuk, S. (2018). Biyofilik tasarım ve iyileştiren mimarlık: sağlık yapıları üzerine bir değerlendirme. EJONS International Journal on Mathematic, Engineering and Natural Sciences, 3(1), 35-47.

Kellert, S. R. (2014). Biophilia and Biomimicry: Evolutionary Adaptation of Human versus Nonhuman Nature. Intelligent Buildings International, 8(2), 51-56.

Nieuwenhuis, M., Knight, C., Postmes, T. (2014). The Relative Benefits of Green versus Lean Office Space: Three Field Experiments. Journal of Experimental Psychology Applied, 20(3), 199-214.

Sevinç Kayıhan, K., Özçelik Güney, S., \& Ünal, F.C. (2018). Biophilia as the Main Design Question inArchitectural Design Studio Teaching. MEGARON,13(1), 1-12.

Wilson, K. (2016). The Use of Biophilic Strategies in the Workplace. People and Strategy, 39(2), 14.

Yılmaz, S., \& Olgan, R. (2017). Okul Öncesi Dönem Çocuklarının Doğaya Yakınlık (Biyofili) Seviyelerinin Araştırılması. Mersin Üniversitesi Eğitim Fakültesi Dergisi, 13(3), 1106-1129.

Yurtgün, Ö. (2020). Biyofilik Tasarım Kriterlerinin Açık Ofisler Üzerinden Değerlendirilmesi. IDA: International Design and Art Journal, 2(2), 281-296.

\section{İnternet Kaynakları}

Kellert, S., \& Calabrese, E. (2015): The Practice of Biophilic Design. www.biophilic-design.com. Erişim Tarihi: 12 Temmuz 2021.

\section{Kitaplar}

Altınay, B., Anşin, R., Bakırcı, A., Bayındır, D., Bilgin, M., Çıngay, B., Denizyaran, A., Disperati, E.E., Gül, S., Gülenç, F., Güner, A., Kanoğlu, S.S., Kılıç, C.S., Kuşoğlu, B., Öcal, Ş., Öztekin, M. \& Yüzbaşıŏlu, S., 2011. Nezahat Gökyiğit Botanik Bahçesi Gezi Rehberi. İstanbul: Nezahat Gökyiğit Botanik Bahçesi Yayınları.

Browning, W.D., Ryan, C., \& Clancy, J. (2014). 14 Patterns of Biophilic Design, Improving Health \& Well-Being in the Built Environment. New York: Terrapin Bright Green.

Engleson, D.C., \& Yockers, D. H. (1994). A Guide to Curriculum Planning in Environmental Education. Madison: ERIC Wisconsin Department of Public Instruction.

Kellert, S.R. (2005). Building For Life: Designing and Understanding The Human-Nature Connection. Washington: Island Press.

Sobel, D. (2008). Children and Nature: Design Principles for Educators. Portland ME: Stenhouse Publishers.

\section{Tezler}

Bayraktaroğlu, Ö.E. (2014). Mimarlıkta Ekosistem Düşüncesiyle Tasarlamak. Yüksek Lisans Tezi, İstanbul Teknik Üniversitesi Fen Bilimleri Enstitüsü, İstanbul. 